\title{
The Effectiveness of ThingLink in Teaching New Vocabulary to Non-Native Beginners of the Arabic Language
}

\author{
Nur Najhah Akmal Roslan \\ Kulliyyah of Education, \\ International Islamic University Malaysia, \\ Kuala Lumpur, Malaysia \\ najhah.akmal16@gmail.com
}

\author{
Muhammad Sabri Sahrir \\ Kulliyyah of Education, \\ International Islamic University Malaysia, \\ Kuala Lumpur, Malaysia \\ muhdsabri@iium.edu.my
}

\begin{abstract}
Low proficiency in the Arabic language, specifically in vocabulary learning, has been a longstanding issue for non-native Arabic speakers. Traditional language pedagogy, such as chalk and talk and memorization, continues to be a widely-known cause of low proficiency that affects 21 st century students. Thus, this study sought to investigate the effectiveness of using ThingLink, an interactive image annotation tool, as an intervention to teach Arabic vocabulary to beginners of the language at a public university in Malaysia. The study adopted a preexperimental design, i.e., the pretest-posttest one group design, involving 30 students who were beginners of Arabic. The Vocabulary Knowledge Scale (VKS) and a modified TAM questionnaire were utilized to examine ThingLink's effectiveness in three aspects, i.e., perceived usefulness, perceived ease of use and students' vocabulary achievement. The data were analyzed descriptively and with a paired samples t-test. The results showed a statistically significant increase in vocabulary achievement among the subjects, but the effect of the intervention was only moderate at Cohen's $d=0.42$. The subjects rated ThingLink positively on both usefulness and ease of use, although their endorsement of the app's ease of use was higher than their rating of its usefulness. The subjects' reactions to ThingLink indicate that it is an effective tool for language teachers and students to use. The results of the study support the use of ThingLink as language learning app capable of meeting the needs and goals of $21^{\text {st }}$ century education.
\end{abstract}

Keywords: Low language proficiency, Arabic vocabulary learning, ThingLink, image annotation tool, Vocabulary Knowledge Scale, non-native Arabic learners, technology utilization

\section{INTRODUCTION}

Vocabulary is the first thing to learn when learning a language. In order to communicate well with others, learners must acquire the vocabulary of the language first, especially if it is a foreign language. Vocabulary is the most fundamental component to be acquired by all language students, be they native speakers or non-native speakers, as having the right amount of vocabulary helps to polish and strengthen the four main skills of reading, writing, speaking and listening. In Malaysia, Arabic is an important foreign language that Islamic studies students must learn. Due to its importance, it has been 
included in the curriculum of several universities (Aliyu, Nurazan, Siti Salwa, \& Ibrahim, 2018). Furthermore, the mastery of Arabic vocabulary benefits students as it (Zunita \& Harun, 2016). As asserted by Hasan and Al-Hasani (2019), students with low Arabic vocabulary knowledge might suffer from fear and anxiety when completing language assessments as they have barriers in expressing themselves. Thus, to be able to learn Arabic successfully, students must possess high levels of vocabulary knowledge throughout their learning process.

The rapid developments made in digital technology have created new ways of learning a language. According to Tautkevičienè and Dubosas (2014), Web 2.0 applications are among the most popular methods for teaching and learning today. Groves and O'Donoghue (2009), as cited in Alasraj and Alharbi (2014), stated that technology can improve students' learning experience. The integration of technology into teaching and learning has shown promising benefits for students in learning a foreign language, including Arabic. Tautkevičienè and Dubosas (2014) also argued that Web applications are able to attract students' attention and get them to engage, collaborate and share knowledge and materials due to their interactive features and interfaces. Leow and Neo (2014) further mentioned that teachers in this digital age often conduct discussions and give lectures using Web-based platforms and multimedia elements. A growing number of teachers also use cloud-based applications to deliver information inside and outside the classroom to enhance students' abilities to think, sharpen their creativity, and facilitate their understanding of the language context. An advantage of technology is that its use allows students to explore multiple sources of information and learn to synthesize ideas, a skill much needed for $21^{\text {st }}$ century learning. In comparison to technology-enhanced teaching, the more traditional direct instructional method of teaching tends to spoon feed information to students, rather than giving them the opportunity to explore knowledge and seek answers for themselves. The learning experience in a traditional classroom tends to be one-sided and noninteractive, where the knowledge often comes solely from the teacher. With digital technology and Web 2.0 applications, the shortcomings of traditional instruction can be overcome. One such application that can be used to make the learning of Arabic vocabulary more interesting and engaging to students is ThingLink. Being a predominantly visual app, ThingLink has the capacity to sustain high levels of attention and interest in learning Arabic vocabulary. It is also an interactive tool that can develop $21^{\text {st }}$ century learning skills such as critical thinking and collaboration among users, in addition to creating a sense of curiosity in students about the subject matter to be learned. With ThingLink's potential in mind, the researchers decided to design an Online Arabic Visual Dictionary (OAVD) with it and test its effectiveness in teaching new Arabic vocabulary to non-native Arabic students at a language learning centre of a public university.

\section{Technology in Teaching and Learning a Second Language}

Several studies have examined the use of technology in modern teaching styles for digital learners. Educational tools and materials in the forms of digital applications, gamification, Web 2.0 platforms, massive open online courses (MOOCs), and the like have been developed and widely employed in contemporary classrooms. In second language learning, the adoption of new and innovative technology is nothing new. Second language educators have, for some time, been integrating technology into the classroom. As indicated by Perikos, Grivokostopoulou, 
Kovas, and Hatzilygeroudis (2015), web applications have been used to facilitate collaborative and distance learning which integrates social interaction between teachers and their students. Plenty of Web 2.0 applications and tools have been developed which combine gamification, presentations, worksheets, digital storytelling and other tools in order to engage students with the learning content and generate an active learning environment. However, the level of technology adoption is much higher among English language teachers than Arabic language teachers (Muhamad Khairul et al., 2019).

A recent survey conducted by Muhamad Khairul et al. (2019) on undergraduates showed that a majority of the current generation of learners preferred Arabic language lessons to be taught by integrating technology into the classroom because they would enjoy the lessons more than solely using the conventional teaching method. Furthermore, the use of virtual reality (VR) and augmented reality (AR), as reported by Muhamad Khairul et al. (2019), would make it easier for students to understand and master Arabic lessons. These findings are supported by Chandrasekera and Yoon (2018), who noted that VR and AR promote higher levels of learning engagement and interaction for all types of learners, be they visual, auditory, and kinesthetic.

\section{Using Thinglink in Teaching Arabic Vocabulary}

One of the Web 2.0 tools that can incorporate VR, AR, and digital media such as instructional video, audio and graphics in its learning objects is ThingLink. ThingLink is regarded as a useful pedagogical tool for teaching Arabic vocabulary. Appasamy (2018) and Inozemtseva, Kirsanova, Troufanova, and Semenova (2018) in their studies revealed that ThingLink is an interactive annotation tool that can be used to teach learners inside and outside the classroom. In fact, ThingLink has been designed with a user-friendly interface to engage students with the learning content. In addition, ThingLink helps students to visualize the newly presented information in three modes: (i) by watching the instructional videos and looking at the pictures associated with it, (ii) by reading relevant texts and brief descriptions, and (iii) by hearing the audio tagged in the ThingLink app (Inozemtseva et al., 2018; Aromahu, \& Wirabhakti, 2019). According to Boyle (2015), ThingLink assists second language educators in utilizing images for language learning, specifically for vocabulary learning.

The accessibility and simplicity of ThingLink have been shown through student feedback. In Appasamy (2018), students reported being able to understand, classify, and discover information by themselves from the histological pictures tagged in ThingLink. This discovery about the potential of ThingLink is significant for enhancing and improving students' creativity and critical thinking skills through the app. Thus, it can be concluded that ThingLink is useful for creating meaningful learning of Arabic vocabulary. The use of ThingLink among students has increased over recent years as they are able to explore, collaborate, invent, inquire, and acquire new knowledge using this app (Appasamy, 2018; Inozemtseva et al., 2018; Aromahu, \& Wirabhakti, 2019). In conclusion, using ThingLink is expected to transform the teaching and learning process from being teacher-oriented to becoming student-oriented, which is a major goal of $21^{\text {st }}$ century education. 


\section{Research Problem}

In the last decade, various studies have found that the teaching and learning process of the Arabic language in Malaysia has not been able to achieve its goals and objectives (Mohamad Rofian et al., 2013). Arabic proficiency among Malay students remains low and dismal. Even though Malaysian students have learned Arabic in school for at least 10 years, they are not able to speak the language fluently and still make grammatical errors (Mohamed Ali, 2013). Despite being taught and educated in a good education system, where they are provided with better textbooks, more qualified teachers and a better curriculum, students' proficiency and performance in Arabic are still below expectations (Mohamad Rofian et al., 2013). Their increasing lack of proficiency in Arabic is even more pronounced when their language skills are compared to the skills of students from yesteryears.

Students' low proficiency in Arabic has been found to be associated with the lack of vocabulary which particularly affects the proficiency levels of beginners (Sueraya, Ahmed, Arifin, Wan Rusli, \& Rawash, 2016; Makhoul \& Sabah, 2019). Previous research shows students still unable to master the four language learning skills despite having learned Arabic syntax (Nahw), morphology (Sarf), and other linguistics aspects of the language. This concern is empirically justified as Malaysian students' achievement in most Arabic subjects has declined (Mohamad Rofian et al., 2013). Apart from that, Zunita, Harun, Lubis, and Nurul Kamalia, (2016) suggested that vocabulary learning is the first thing to do in learning the Arabic language. However, many students could not develop the vocabulary due to a lack of understanding of the context in which the vocabulary should be used. The authors contended that students will acquire the four language learning skills when they become proficient in Arabic vocabulary.

Many research findings revealed that Arabic classes are uninteresting as teachers used the same methods of teaching repeatedly (Norfaezah, 2014; Raja Hazirah et al., 2017). As posited by Norfaezah (2015), direct instruction, lectures, or teacher presentations are among the common teaching methods implemented by Arabic educators for the past ten years. These methods, which are heavily teacher-centred, should be reduced in order to obtain higher achievement, satisfaction, positive attitude, higher-level cognitive skills, and motivation among students. Instead of using the same instructional methods throughout the semester, various teaching styles should be used to attract and sustain students' attention, and to make Arabic language classes more interactive and effective (Nurkhamimi \& Muhammad Sabri, 2016). Arabic language teachers should employ more student-centred strategies, such as storytelling, which has been shown to be an effective means of teaching Arabic vocabulary (Nur Farhanah \& Arifin, 2017).

Technology-enhanced approaches, such as the use of digital apps in teaching language skills and vocabulary, are seen as one of the potential solutions to this issue. Previous studies suggest that Web 2.0 applications are suitable for the current generation as they are living in a digital age (Farmer, 2011; Konstantinidis, Theodostadou, \& Pappos, 2013). Thus, technology can help students to enhance their understanding of the language context. Many previous studies including Martinez (2010) and Appasamy (2018) found that most students are more satisfied when learning using technology as compared to the face-to-face approach. In learning Arabic, 
technology can be used as a tool to enhance learning and improve students' vocabulary acquisition. In addition, as discovered by Taha (2019) in his research involving non-native Arabic students at a public university's language learning centre, most beginning students of Arabic are unable to join Arabic letters in their writing properly. Problems such as this and the lack of contextual understanding of Arabic vocabulary could be addressed with the use of digital technology. Therefore, in this study, the ThingLink application was used to create a visual dictionary tagged with audio, images and videos to teach the pronunciation and meaning of selected Arabic vocabulary. The dictionary was expected to make students understand the Arabic words better through its visual and audio stimuli, and show them how to write and spell the words properly through the instructional videos tagged in it. In addition, the design of ThingLink was based on Paivio's (1991) Dual Coding Theory that stipulates the combined capacity of the visual and auditory channels in effectively processing information leading to the meaningful acquisition of new knowledge. Hence, drawing upon the premises of the dual coding theory, this study was conducted to explore the effectiveness of a ThingLink visual dictionary in teaching Arabic vocabulary to non-native beginning students of the language.

\section{Research Objective}

The objective of the study is to determine the extent to which an Online Arabic Visual Dictionary (OAVD) created using ThingLink is effective in helping non-native students acquire new Arabic vocabulary. Effectiveness in this research context refers to the OAVD's usefulness and ease of use in learning Arabic vocabulary as perceived by the students. Effectiveness is also measured by the students' vocabulary gain scores between the pretest and posttest administered before and after the OAVD.

\section{Conceptual Framework}

Based on Paivio's dual coding theory, Figure 1 shows the study's postulation of how Arabic vocabulary is developed using the OAVD (created with ThingLink) through active verbal and non-verbal processing of the associated visual and audio stimuli.

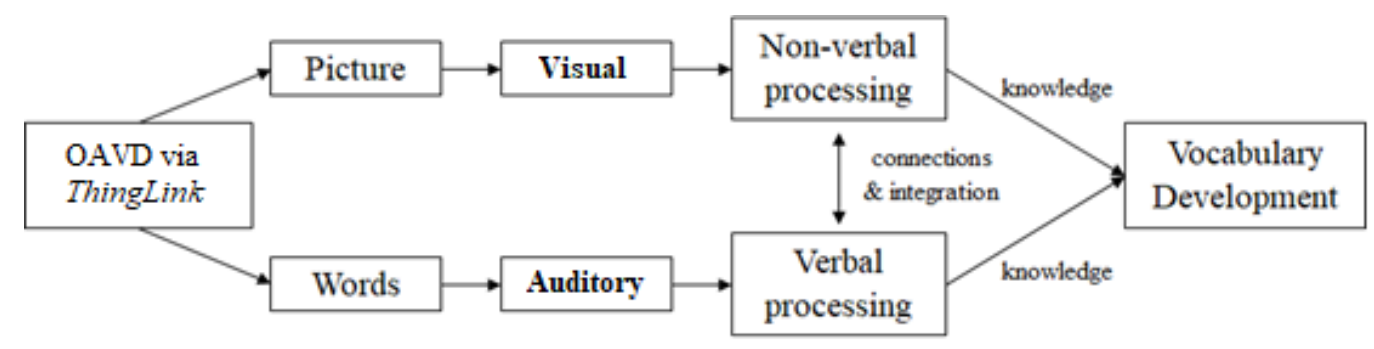

Figure 1: Arabic Vocabulary Development with OAVD via Paivio's (1991) Dual Coding Theory

The OAVD was designed based on Paivio's theory and developed using pictures, words and videos tagged into the ThingLink app. The visual and auditory stimuli required the students to engage in verbal and non-verbal processing of the new vocabulary using their eyes and ears. 
Hence, both their visual and auditory channels would be activated in the learning process aided by ThingLink. From the connections and integration of these two information processing activities, students should gain an enhanced understanding of the newly presented Arabic vocabulary. Figure 2 shows the effects of the OAVD conceptualized using a combination of Paivio's dual coding theory and Davis' (1989) Technology Acceptance Model (TAM). TAM posits that two factors influence users' acceptance of new technology, namely perceived usefulness (i.e., benefits of using the technology) and perceived ease of use (i.e., how easy it is to use the technology). In the present study, the OAVD's effectiveness are established using these two measures in addition to students' vocabulary gain scores.

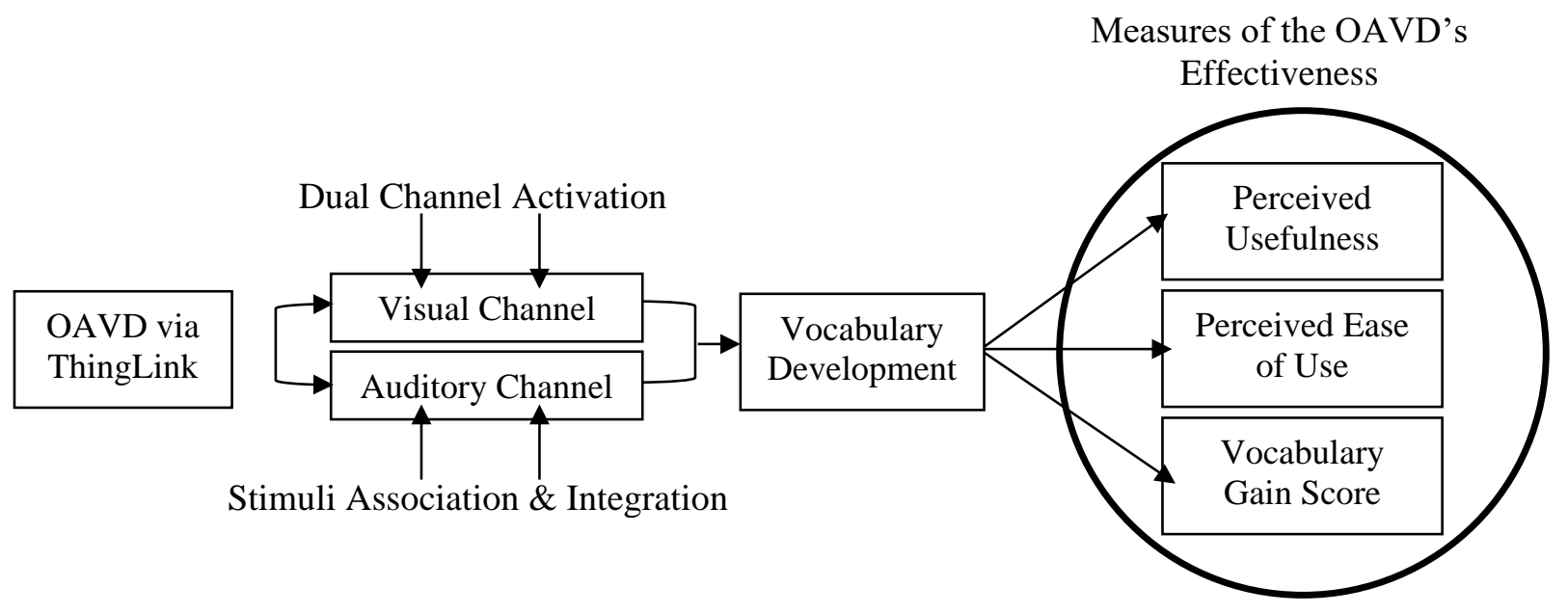

Figure 2: Conceptual Framework Based on Paivio (1991) and Davis (1989)

In addition to students' vocabulary learning gains, TAM constructs were added to measure the effectiveness of the OAVD in imparting Arabic vocabulary to non-native students. TAM is widely adopted by researchers in studying technology acceptance and success factors. As mentioned by Adnan, Fahmi Zaidi, Azlina, and Wan Salihin (2016), these two constructs can be used to explain the success of ThingLink in vocabulary teaching by capturing students' perceptions of its benefits and ease of use.

\section{METHODOLOGY}

\section{Research Design}

This study was conducted using a pre-experimental design with an intact class, where only one group of students was involved in testing the effectiveness of the OAVD. Specifically, the design is a one-group pretest-posttest design that can be schematically represented as follows in Table 1:

Table 1

The Study's Pre-Experimental Design

\begin{tabular}{llll}
\hline Intact-Group & $\mathrm{O}_{1}$ & $\mathrm{X}$ & $\mathrm{O}_{2}$ \\
\hline
\end{tabular}

Notes: $\mathrm{O}_{1}=$ Observation (Pretest); $\mathrm{X}=$ The OAVD (ThingLink) Treatment; $\mathrm{O}_{2}=$ Observation (Posttest) 
Prior to the intervention, the subjects' prior knowledge was assessed using a pretest. Before the OAVD, the subjects learned Arabic vocabulary via traditional language pedagogy (i.e., direct instruction). Then they were given the OAVD on ThingLink to study 20 new words on their own. A posttest to measure the subjects' vocabulary learning gains was administered after the OAVD intervention was completed.

\section{Sample}

An intact class of 30 Arabic language beginners $(\mathrm{N}=30)$ at a Malaysian public university were chosen to receive the OAVD intervention via ThingLink. They were direct intake students who did not pass the university's Arabic Placement Test (APT), and were taking two courses on Arabic grammar and vocabulary in Semester 1 of the 2019/2020 academic year. Students in these two courses differed in terms of their prior knowledge of Arabic, writing skills, and vocabulary (Taha, 2019). They were required to pass the two subjects before they could proceed with their core courses. They were randomly drawn from three different classes, one of which was a Level 1 class (absolute beginners), while the other two were Level 2 classes (advanced beginners).

In terms of gender composition, they were $70 \%$ female $(n=21)$ and $30 \%$ male $(n=9)$. A majority of the subjects were between 19 and 21 years of age $(56.7 \%)$, followed by $23.3 \%$ in the range of 22 and 24, and 20\% in the range of 25 and 27. Most were Malaysian students (90\%) from the Kulliyyahs of Islamic Revealed Knowledge and Human Sciences (30\%), Economics and Management Sciences (16.7\%), Engineering (13.3\%), Information and Communication Technology (13.3\%), Centre for Languages and Pre-University Academic Development (10\%), Education (10\%), and finally, Architecture and Environmental Design (6.7\%). The classes were handpicked by the language center's Deputy Director based on his knowledge of their proficiency levels. In these classes, dictation was used by the lecturers to help students relate words sounds with their written forms.

\section{Intervention}

ThingLink was used to create the study's intervention, which was an Online Arabic Visual Dictionary, or OAVD for short. ThingLink is a Web 2.0 image annotation tool that can be used to create an interactive platform embedding sounds, graphics and videos appropriate for teaching Arabic vocabulary. This intervention was designed by the researchers based on Paivio's (1986) dual coding theory that postulates that students learn more effectively when both their audio and visual channels are activated. In other words, the theory asserts that students are able to process and recall new information better when it is presented to them in both visual and verbal forms. Screenshots of the OAVD employed in this study are shown in Figures 3 to 5 . 


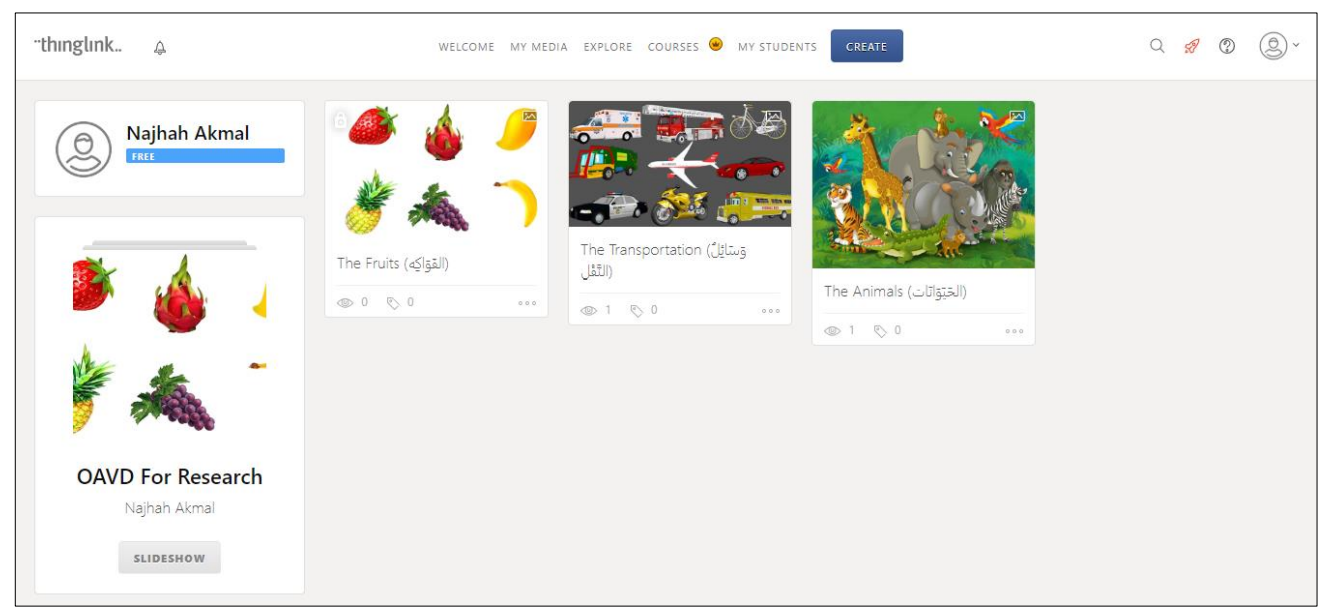

Figure 3: Screenshot of the OAVD's Topics on Fruits, Animals and Transportation

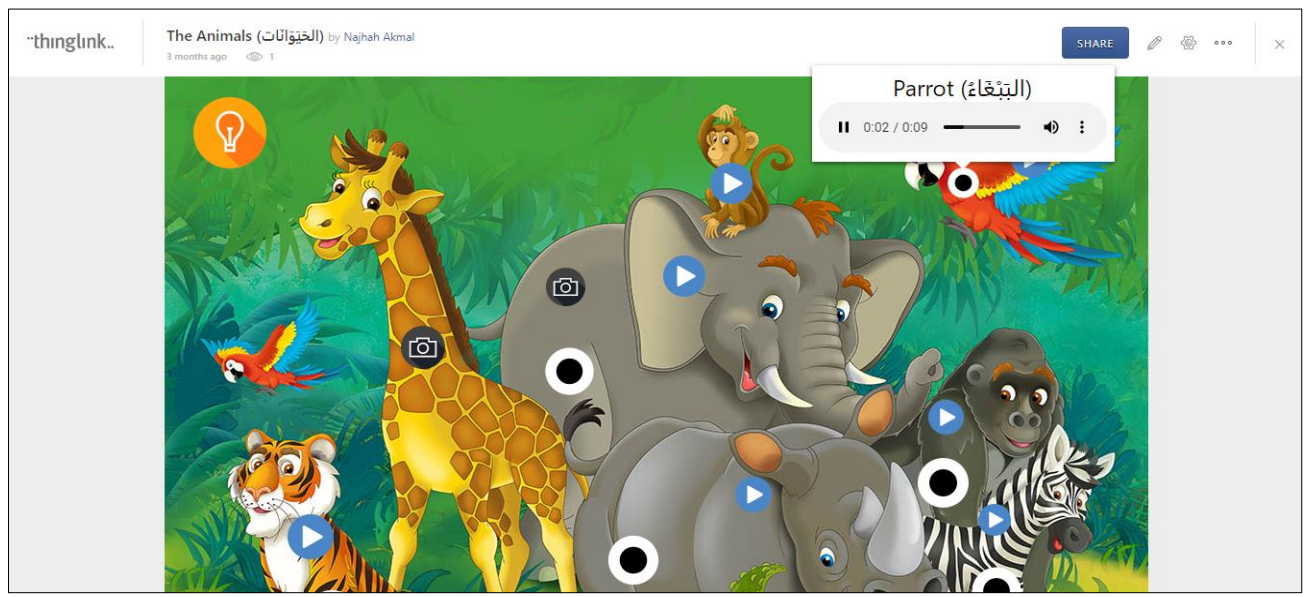

Figure 4: Screenshot of Audio-Tagged English and Arabic Words in the OAVD

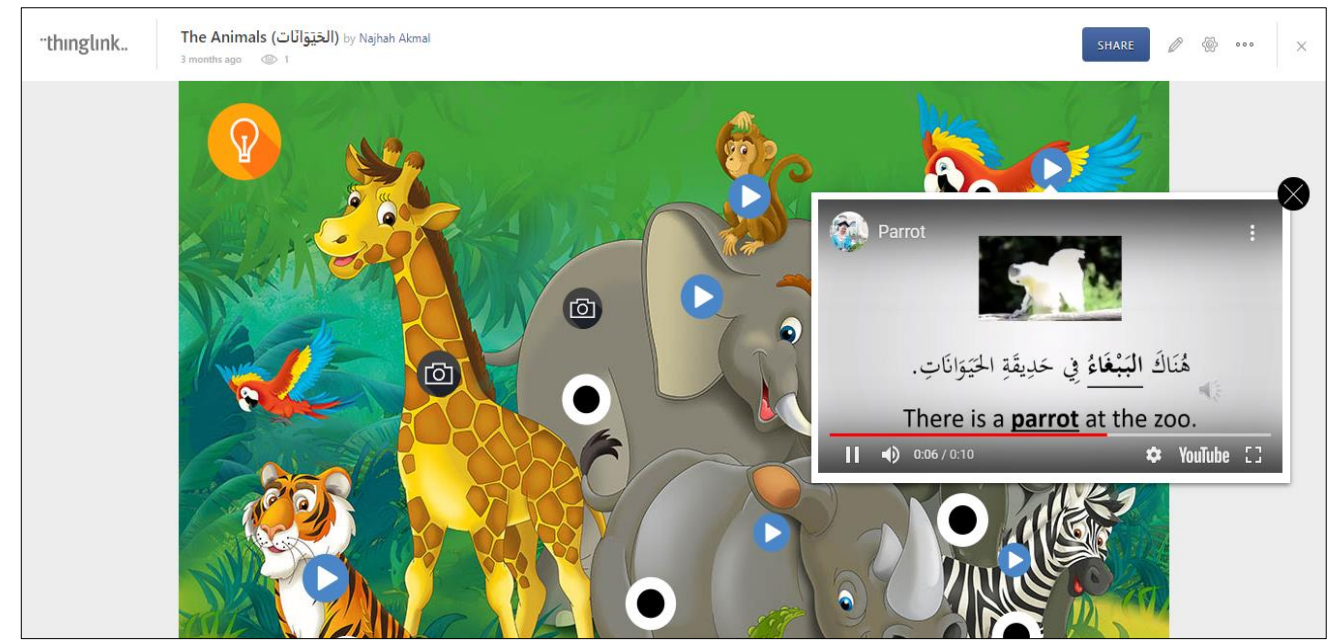

Figure 5: Screenshot of Video-Tagged English and Arabic Words in the OAVD

The OAVD was annotated with the images of fruits, animals and transportation and designed to be highly interactive to facilitate the subjects' new vocabulary acquisition. Its utility was also enhanced by the pronunciation of the 20 new words via audio and video tagged to the relevant images. The tagged multimedia elements also included animated GIFs and sample sentences in English and Arabic showing the correct uses of each word. The multimedia elements used in the OAVD activated the subjects' visual and auditory channels which subsequently facilitated their learning of the new Arabic vocabulary. 


\section{Content or Material}

For this study, the OAVD was designed to teach twenty (20) new Arabic words around three (3) topics in the language center's Arabic language syllabus, namely animals (8 words), fruits (6 words), and transportation (6 words). The list of words together with their meaning in English is given in Table 2 .

Table 2

List of 20 Arabic Words Taught in This Study via the OAVD

\begin{tabular}{|c|c|}
\hline Meaning & Arabic Word \\
\hline strawberry & 1) الفر اولة \\
\hline mango & 2) المانجو \\
\hline banana & 3) الموز \\
\hline dragon fruit & 4) فاكهة التتين \\
\hline pineapple & 5) الأناناس \\
\hline grapes & 6) العنب \\
\hline parrot & 7) الببغاء \\
\hline elephant & 8) الفيل \\
\hline monkey & 9) القرد \\
\hline zebra & 10) الحمار الوحشي \\
\hline gorilla & 11) الغوريلا \\
\hline tiger & 12) النمر \\
\hline rhinoceros & 13) وحيد القرن \\
\hline crocodile & 14) التمساح \\
\hline bicycle & 15) الدر اجة \\
\hline garbage truck & 16) شـاحنة قمامة \\
\hline police car & 17) سيارة شرطة \\
\hline fire truck/garbage & 18) سيارة إطفاء \\
\hline motorcycle & 19) در اجة نارية \\
\hline school bus & 20) حافلة مدرسة \\
\hline
\end{tabular}

Each of the 20 words was tagged with suitable instructional videos, pictures, and audios in the OAVD to facilitate students' learning of the new Arabic vocabulary. 


\section{Instruments}

Two instruments were used in this study to measure the dependent variables, namely (i) the OAVD's effect on students' Arabic vocabulary learning; and (ii) students' perceptions of its usefulness (i.e., perceived usefulness or PU) and ease of use (PEOU). The two instruments are described separately below.

\section{Vocabulary Knowledge Scale (VKS)}

For the pretest and posttest, the researcher employed the Vocabulary Knowledge Scale (VKS) developed by Wesche and Paribakht (1996). The function of this scale was to assess the subjects' knowledge of the new Arabic vocabulary before and after the OAVD intervention. The VKS is a 5-item self-reported scale that measures Arabic vocabulary gain scores between the pretest and posttest. It starts with word recognition items first (that are given a score of 1 or 2), followed by application items that assess whether the subjects know how to use the words in a sentence (these are given a score of 5). If a subject chooses the statement, "I don't remember having seen this word before, " he/she will be given a score of 1, which is the lowest score in the VKS. If the subject chooses the statement, "I can use this word in a sentence," he/she will be awarded a score of 5, which is the highest score in the scale. The 5-item VKS is shown in Table 3 below.

Table 3

The Vocabulary Knowledge Scale (Wesche \& Paribakht, 1996)

\begin{tabular}{lc}
\hline \multicolumn{1}{c}{ Items Showing Levels of Vocabulary Learning } & Score \\
\hline 1. I don't remember having seen this word before. & 1 \\
2. I have seen this word before but I don't know what it means. & 2 \\
3. I have seen this word before and I think it means & 3 \\
4. I know this word. It means _. & 4 \\
5. I can use this word in a sentence. & 5 \\
\hline
\end{tabular}

The VKS was administered twice in the study--first as a pretest prior to the intervention, and then, as a posttest after they had studied the new Arabic vocabulary via the OAVD. In each session, the subjects were asked to assess or report their level of vocabulary knowledge for each of the words taught.

\section{ThingLink's PU and PEOU Questionnaire}

This Likert questionnaire had three sections containing 10 items that measured the students' perceptions of ThingLink's usefulness and ease of use as a vocabulary learning app on a 5-point agreement scale (from Strongly Agree to Strongly Disagree). Its function in the study was to evaluate ThingLink as an Arabic learning app in terms of its general benefits and how easy it was to use. Section A consisted of items on the subjects' demography such as gender, age, nationality, and kulliyyah. Section B surveyed the perceived usefulness of ThingLink in learning Arabic vocabulary. The items sought to establish how ThingLink benefited the subjects, who were non-native Arabic speakers, in learning Arabic vocabulary, and were 
adapted from Muhammad Sabri and Mohammad Taufiq (2016). Section C measured the extent to which the OAVD/ThingLink was perceived as easy to use using items that were adapted from Lund (2001) and Davis (1989). Both Sections A and B consisted of 10 items each. The breakdown of items and their sources are shown in Table 4.

Table 4

The PU-PEOU Questionnaire, Sources of Items and Reliability Estimates

\begin{tabular}{clcl}
\hline Section & \multicolumn{1}{c}{ Variable } & No of Items & \multicolumn{1}{c}{ Source } \\
\hline A & Demographic data & 5 & Self-developed \\
B & $\begin{array}{l}\text { Perceived Usefulness of } \\
\text { the OAVD/ThingLink }\end{array}$ & 10 & $\begin{array}{l}\text { Muhammad Sabri \& } \\
\text { Mohammad Taufiq (2016) }\end{array}$ \\
C & $\begin{array}{l}\text { Perceived Ease of Use } \\
\text { of OAVD/ThingLink }\end{array}$ & 9 & Lund (2001); Davis (1989) \\
\hline
\end{tabular}

\section{Instrument Validity and Reliability}

The two questionnaires used in the study were checked for content validity by a two-expert panel. Hence, the validity of the items measuring vocabulary knowledge, perceived usefulness and perceived ease of use was verified via expert judgment. In terms of reliability, based on the study's data from 30 subjects, the internal consistency of the VKS was estimated at $\alpha=0.841$. Perceived usefulness was also reported to demonstrate a high Cronbach's alpha in previous studies, i.e., $\alpha=0.868$ in Muhammad Sabri and Mohammad Taufiq (2016). Meanwhile, Lund (2001) and Davis (1989) disclosed an alpha of more than 0.8 for perceived ease of use. Thus, both measures have been established to have high internal consistency estimates. Based on this study's data, PU's reliability was $\alpha=.91$, while that of PEOU was $\alpha=.85$.

\section{Data Collection Procedures}

The study was conducted in Semester 1 of the 2019/2020 academic session where the subjects had to learn the Arabic language for four months via face-to-face traditional learning with their lecturers. Prior to this semester, the researchers developed the interactive OAVD via ThingLink to be used as the intervention. Three different classes comprising 30 Level 1 (absolute beginner) and Level 2 (advanced beginner) students were selected to participate as subjects of the study by the language centre's Deputy Director. In the first phase of data collection, using traditional direct instruction, the researchers taught new Arabic vocabulary around the topics of Fruits, Animals and Transportation to the subjects. The VKS was then administered as a pretest to assess the subjects' knowledge of the vocabulary. The researchers briefly explained the VKS to the subjects, specifically on how to respond to the items. Fifty (50) minutes were allocated for the VKS administration. At the end of this exercise, the VKS copies were collected from the subjects with each copy given an ID number for tracking and data analysis.

A week following the pretest, the subjects were taught the 20 new words again, but this time via the OAVD. Three hours were spent on teaching the words using the ThingLink app. 
A week following the pretest, the subjects were taught the 20 new words again, but this time via the OAVD. Three hours were spent on teaching the words using the ThingLink app. After completing the ThingLink lessons, the researchers administered the VKS again as a posttest to assess the subjects' vocabulary knowledge development, as well as the PU-PEOU questionnaire to assess the subjects' perceptions of the OAVD/ThingLink's effectiveness as a vocabulary learning app. The same amount of time, i.e., 50 minutes, was allocated for the posttest. The complete data collection procedures took about two weeks. The study's 7-step data collection procedures are illustrated in Figure 6.

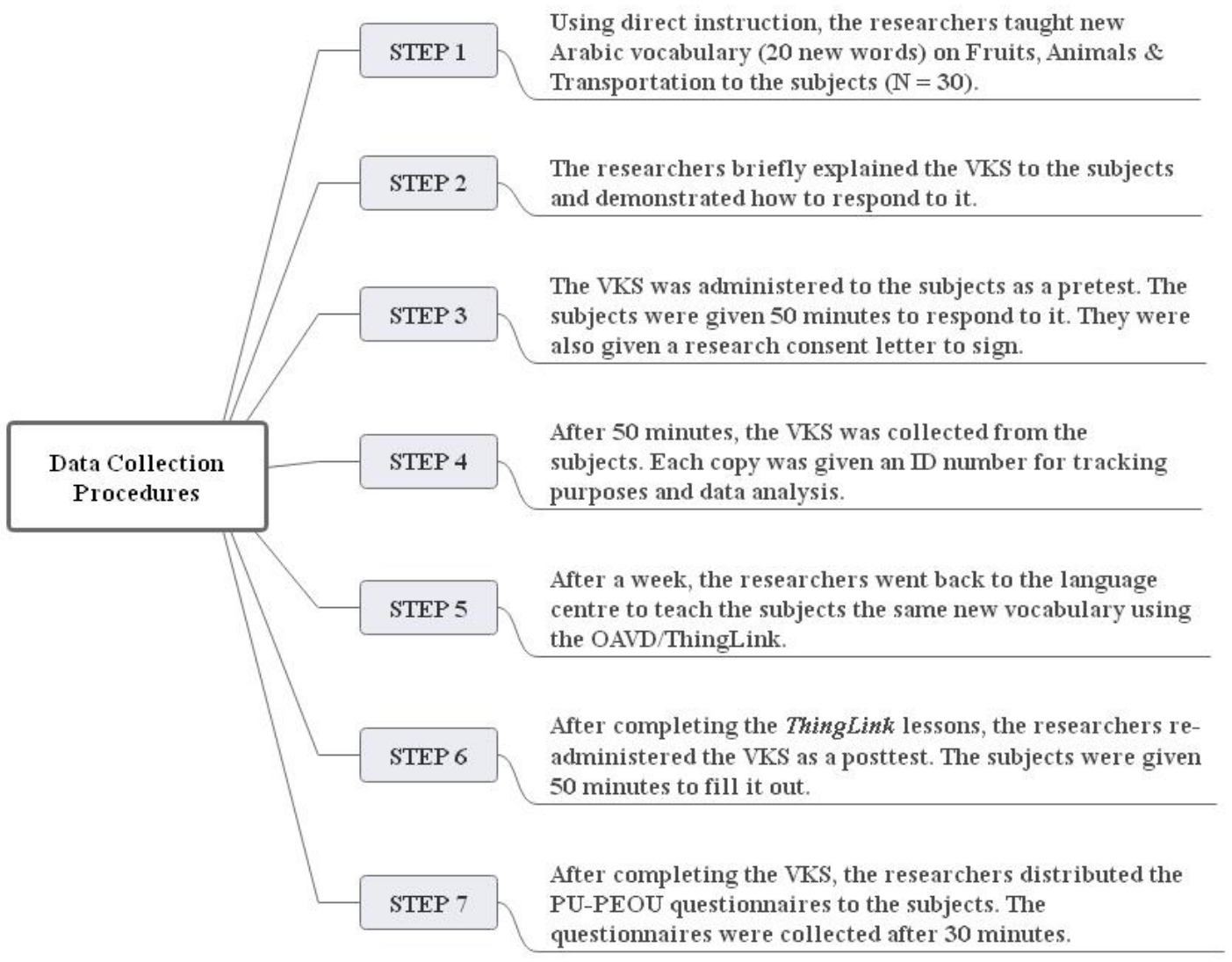

Figure 6: Data Collection Procedures

\section{Data Analysis}

In order to scrutinize the data normality distribution, a Shapiro-Wilk test was run before analyzing the data. Ghasemi and Zahediasl (2012) explained that the Shapiro-Wilk test is used in studies with a sample size smaller than 50. This test was run to decide whether the study should use a parametric or a non-parametric test to arrive at the results. Table 5 shows the outcomes of the test.

Table 5

Shapiro-Wilk Test Results $(\mathrm{N}=30)$

\begin{tabular}{lcc}
\hline \multicolumn{1}{c}{ Construct } & Label & Sig. \\
\hline Total Perceived Usefulness & PU & 0.551 \\
Total Perceived Ease of Use & PEOU & 0.298 \\
Arabic Vocabulary Score & PRE & 0.757 \\
Arabic Vocabulary Score & POST & 0.839 \\
\hline
\end{tabular}


As described in Table 5, the $p$ values for all constructs examined in this study were higher than the alpha value $(\alpha=0.05)$. The results indicate a normal distribution of the data as the $p$ values for all constructs were not statistically significant (Shamshuritawati, 2019). In other words, the data collected from the subjects were normally distributed as $p_{\text {pre }}=0.757, p_{\text {post }}=0.839, p_{\text {pu }}=$ 0.551 , and $p_{\text {peou }}=0.298$. Therefore, the researchers decided to employ a parametric test to analyze the data on the effectiveness of the OAVD/ThingLink. First, a paired-sample t-test was utilized to examine whether there is a significant difference between the subjects' VKS scores before (i.e., pretest) and after the OAVD (i.e., posttest). Second, to establish the extent of the OAVD/ThingLink's perceived usefulness and ease of use, descriptive statistics were used.

\section{RESULTS}

To reiterate, the OAVD's or ThingLink's effectiveness was assessed using three measures or constructs, namely perceived usefulness, perceived ease of use, and vocabulary gain scores captured through the VKS. The results for each are presented in separate subsections.

\section{Perceived Usefulness of the OAVD/ThingLink Application}

In this study, perceived usefulness of the OAVD/ThingLink was assessed using ten items. The subjects' perceptions of its usefulness were analyzed descriptively using frequencies, percentages, means, and also standard deviations. The results of this descriptive analysis are exhibited in Table 6.

Table 6

The OAVD/ThingLink's Perceived Usefulness: Distribution of Responses $(\mathrm{N}=30)$

\begin{tabular}{|c|c|c|c|c|c|c|c|}
\hline \multirow{2}{*}{ Items } & \multicolumn{5}{|c|}{ Level of Agreement } & \multirow{2}{*}{$\mathbf{M}$} & \multirow{2}{*}{ SD } \\
\hline & SD & $\mathbf{D}$ & $\mathbf{N}$ & $\mathbf{A}$ & $\mathbf{S A}$ & & \\
\hline 1. The ThingLink app works well for me & $\begin{array}{c}0 \\
(0)\end{array}$ & $\begin{array}{c}1 \\
(3.3)\end{array}$ & $\begin{array}{c}9 \\
(30.0)\end{array}$ & $\begin{array}{c}16 \\
(53.3)\end{array}$ & $\begin{array}{c}4 \\
(13.3)\end{array}$ & 3.77 & .728 \\
\hline $\begin{array}{l}\text { 2. The ThingLink app works for a long- } \\
\text { term study }\end{array}$ & $\begin{array}{c}0 \\
(0)\end{array}$ & $\begin{array}{c}1 \\
(3.3)\end{array}$ & $\begin{array}{c}9 \\
(30.0)\end{array}$ & $\begin{array}{c}14 \\
(46.7)\end{array}$ & $\begin{array}{c}6 \\
(20.0)\end{array}$ & 3.83 & .791 \\
\hline $\begin{array}{l}\text { 3. I no longer buy highly-priced books } \\
\text { because I can find alternative study } \\
\text { resources in ThingLink }\end{array}$ & $\begin{array}{c}0 \\
(0)\end{array}$ & $\begin{array}{c}5 \\
(16.7)\end{array}$ & $\begin{array}{c}10 \\
(33.3)\end{array}$ & $\begin{array}{c}10 \\
(33.3)\end{array}$ & $\begin{array}{c}5 \\
(16.7)\end{array}$ & 3.50 & .974 \\
\hline $\begin{array}{l}\text { 4. I no longer use large-sized dictionaries } \\
\text { because I can find an alternative way } \\
\text { to study word meanings in ThingLink }\end{array}$ & $\begin{array}{c}0 \\
(0)\end{array}$ & $\begin{array}{c}3 \\
(10.0)\end{array}$ & $\begin{array}{c}10 \\
(33.3)\end{array}$ & $\begin{array}{c}12 \\
(40.0)\end{array}$ & $\begin{array}{c}5 \\
(16.7)\end{array}$ & 3.63 & .890 \\
\hline $\begin{array}{l}\text { 5. The ThingLink application has } \\
\text { improved my Arabic vocabulary }\end{array}$ & $\begin{array}{c}0 \\
(0)\end{array}$ & $\begin{array}{c}2 \\
(6.7)\end{array}$ & $\begin{array}{c}11 \\
(36.7)\end{array}$ & $\begin{array}{c}11 \\
(36.7)\end{array}$ & $\begin{array}{c}6 \\
(20.0)\end{array}$ & 3.70 & .877 \\
\hline
\end{tabular}
knowledge 
Table 6 Continued

\begin{tabular}{|c|c|c|c|c|c|c|c|}
\hline \multirow{2}{*}{ Items } & \multicolumn{5}{|c|}{ Level of Agreement } & \multirow{2}{*}{$\mathbf{M}$} & \multirow{2}{*}{ SD } \\
\hline & SD & $\mathbf{D}$ & $\mathbf{N}$ & $\mathbf{A}$ & $\mathbf{S A}$ & & \\
\hline $\begin{array}{l}\text { 6. The ThingLink application has } \\
\text { improved my Arabic language skills }\end{array}$ & $\begin{array}{c}0 \\
(0)\end{array}$ & $\begin{array}{c}2 \\
(6.7)\end{array}$ & $\begin{array}{c}14 \\
(46.7)\end{array}$ & $\begin{array}{c}12 \\
(40.0)\end{array}$ & $\begin{array}{c}2 \\
(6.7)\end{array}$ & 3.47 & .730 \\
\hline $\begin{array}{l}\text { 7. I think I will learn better through } \\
\text { ThingLink because it provides } \\
\text { opportunities for self-learning }\end{array}$ & $\begin{array}{c}0 \\
(0)\end{array}$ & $\begin{array}{c}0 \\
(0)\end{array}$ & $\begin{array}{c}6 \\
(20.0)\end{array}$ & $\begin{array}{c}19 \\
(63.3)\end{array}$ & $\begin{array}{c}5 \\
(16.7)\end{array}$ & 3.97 & .615 \\
\hline $\begin{array}{l}\text { 8. I can use ThingLink more often than } \\
\text { other applications }\end{array}$ & $\begin{array}{c}0 \\
(0)\end{array}$ & $\begin{array}{c}2 \\
(6.7)\end{array}$ & $\begin{array}{c}9 \\
(30.0)\end{array}$ & $\begin{array}{c}16 \\
(53.3)\end{array}$ & $\begin{array}{c}3 \\
(10.0)\end{array}$ & 3.67 & .758 \\
\hline $\begin{array}{l}\text { 9. ThingLink helps me to acquire new } \\
\text { Arabic words successfully }\end{array}$ & $\begin{array}{c}0 \\
(0)\end{array}$ & $\begin{array}{c}0 \\
(0)\end{array}$ & $\begin{array}{c}7 \\
(23.3)\end{array}$ & $\begin{array}{c}18 \\
(60.0)\end{array}$ & $\begin{array}{c}5 \\
(16.7)\end{array}$ & 3.93 & .640 \\
\hline \multirow[t]{2}{*}{$\begin{array}{l}\text { 10. ThingLink makes learning Arabic } \\
\text { vocabulary interesting }\end{array}$} & $\begin{array}{c}1 \\
(3.3)\end{array}$ & $\begin{array}{c}1 \\
(3.3)\end{array}$ & $\begin{array}{c}4 \\
(13.3)\end{array}$ & $\begin{array}{c}15 \\
(50.0)\end{array}$ & $\begin{array}{c}9 \\
(30.0)\end{array}$ & 4.00 & .947 \\
\hline & \multicolumn{5}{|c|}{ Mean Percentage of Agreement } & $\begin{array}{l}64.34 \% \\
3.747\end{array}$ & \\
\hline
\end{tabular}

Overall, the mean percentage of agreement to the PU items is $64.34 \%$, which suggests that the statements stating the general usefulness of ThingLink were accepted by more than $60 \%$ of the subjects. Specifically, a majority of them agreed that learning Arabic vocabulary through ThingLink is interesting ( $80 \% ; \mathrm{M}=4.00)$; they will learn better through ThingLink as it provides opportunities for self-learning (80\%; $\mathrm{M}=3.97)$; and that they have acquired new Arabic words as a result of learning with ThingLink (76.7\%; $\mathrm{M}=3.93)$. More than $60 \%$ also agreed that ThingLink offers a good long-term study method $(66.7 \%$; $\mathrm{M}=3.83)$, and works well for them (66.6\%; $\mathrm{M}=3.77$ ). About $63 \%$ reported they can deal with the ThingLink application often as compared to other applications $(63.3 \% ; \mathrm{M}=3.67)$.

Although still a majority, lesser percentages agreed ThingLink has improved their Arabic vocabulary knowledge $(56.7 \%$; $\mathrm{M}=3.70)$, and they no longer use dictionaries to study word meanings as ThingLink has given an alternative method for word study (56.7\%; $\mathrm{M}=3.63)$. About half of the subjects reported no longer needing to buy expensive books as alternative resources can be found in ThingLink (50\%; M=3.50). However, less than half agreed that the app has succeeded in improving their Arabic language skills (46.7\%; M=3.47). Generally, the patterns of responses and percentages of agreement appear to support the perceived usefulness of the OAVD/ThingLink. 


\section{Perceived Ease of Use of the OAVD/ThingLink}

Ten (10) items measured the OAVD or ThingLink's perceived ease of use. The subjects' responses to the 10 items were analyzed descriptively with frequencies, percentages, means and standard deviations. The results are displayed in Table 7

Table 7

The OAVD/ThingLink's Perceived Ease of Use: Distribution of Responses ( $\mathrm{N}=30)$

\begin{tabular}{|c|c|c|c|c|c|c|c|}
\hline \multirow{2}{*}{ Items } & \multicolumn{5}{|c|}{ Level of Agreement } & \multirow{2}{*}{$\mathbf{M}$} & \multirow{2}{*}{ SD } \\
\hline & SD & $\mathbf{D}$ & $\mathbf{N}$ & $\mathbf{A}$ & $\mathbf{S A}$ & & \\
\hline 1. ThingLink is easy to use & $\begin{array}{c}0 \\
(0)\end{array}$ & $\begin{array}{c}0 \\
(0)\end{array}$ & $\begin{array}{c}3 \\
(10.0)\end{array}$ & $\begin{array}{c}20 \\
(66.7)\end{array}$ & $\begin{array}{c}7 \\
(23.3)\end{array}$ & 4.13 & .571 \\
\hline 2. ThingLink is simple to use & $\begin{array}{c}0 \\
(0)\end{array}$ & $\begin{array}{c}1 \\
(3.3)\end{array}$ & $\begin{array}{c}2 \\
(6.7)\end{array}$ & $\begin{array}{c}20 \\
(66.7)\end{array}$ & $\begin{array}{c}7 \\
(23.3)\end{array}$ & 4.10 & .662 \\
\hline 3. ThingLink is user-friendly & $\begin{array}{l}0 \\
(0)\end{array}$ & $\begin{array}{c}0 \\
(0)\end{array}$ & $\begin{array}{c}4 \\
(13.3)\end{array}$ & $\begin{array}{c}20 \\
(66.7)\end{array}$ & $\begin{array}{c}6 \\
(20.0)\end{array}$ & 4.07 & .583 \\
\hline 4. ThingLink is flexible & $\begin{array}{c}1 \\
(3.3)\end{array}$ & $\begin{array}{c}0 \\
(0)\end{array}$ & $\begin{array}{c}4 \\
(13.3)\end{array}$ & $\begin{array}{c}21 \\
(70.0)\end{array}$ & $\begin{array}{c}4 \\
(13.3)\end{array}$ & 3.90 & .759 \\
\hline $\begin{array}{l}\text { 5. Using ThingLink as a learning aid } \\
\text { is effortless }\end{array}$ & $\begin{array}{c}0 \\
(0)\end{array}$ & $\begin{array}{c}1 \\
(3.3)\end{array}$ & $\begin{array}{c}8 \\
(26.7)\end{array}$ & $\begin{array}{c}16 \\
(53.3)\end{array}$ & $\begin{array}{c}5 \\
(16.7)\end{array}$ & 3.83 & .747 \\
\hline $\begin{array}{l}\text { 6. Learning through ThingLink is } \\
\text { easy for me }\end{array}$ & $\begin{array}{c}0 \\
(0)\end{array}$ & $\begin{array}{c}3 \\
(10.0)\end{array}$ & $\begin{array}{c}4 \\
(13.3)\end{array}$ & $\begin{array}{c}18 \\
(60.0)\end{array}$ & $\begin{array}{c}5 \\
(16.7)\end{array}$ & 3.83 & .834 \\
\hline $\begin{array}{l}\text { 7. My interaction with ThingLink is } \\
\text { clear and understandable }\end{array}$ & $\begin{array}{c}0 \\
(0)\end{array}$ & $\begin{array}{c}2 \\
(6.7)\end{array}$ & $\begin{array}{c}5 \\
(16.7)\end{array}$ & $\begin{array}{c}18 \\
(60.0)\end{array}$ & $\begin{array}{c}5 \\
(16.7)\end{array}$ & 3.87 & .776 \\
\hline $\begin{array}{l}\text { 8. I do not notice any inconsistencies } \\
\text { when I use ThingLink as a learning } \\
\text { aid }\end{array}$ & $\begin{array}{c}0 \\
(0)\end{array}$ & $\begin{array}{c}2 \\
(6.7)\end{array}$ & $\begin{array}{c}11 \\
(36.7)\end{array}$ & $\begin{array}{c}15 \\
(50.0)\end{array}$ & $2(6.7)$ & 3.57 & .728 \\
\hline $\begin{array}{l}\text { 9. It will be easy for me to become } \\
\text { skillful at using ThingLink }\end{array}$ & $\begin{array}{c}0 \\
(0)\end{array}$ & $\begin{array}{c}1 \\
(3.3)\end{array}$ & $\begin{array}{c}6 \\
(20.0)\end{array}$ & $\begin{array}{c}20 \\
(66.7)\end{array}$ & $\begin{array}{c}3 \\
(10.0)\end{array}$ & 3.83 & .648 \\
\hline
\end{tabular}

Mean Percentage of Agreement $78.53 \%$

Construct Mean 3.903

In general, based on Table 7, the mean percentage of agreement to the OAVD's or ThingLink's ease of use is $78.53 \%$. An overwhelming $90 \%$ of the subjects agreed that ThingLink is easy ( $90 \% ; M=4.13)$ and simple to use $(90 \% ; M=4.10)$, while more than $80 \%$ felt it userfriendly $(86.7 \% ; \mathrm{M}=4.07)$ and flexible $(83.3 \% ; \mathrm{M}=3.90)$. Most subjects also rated the app as easy to use as their interaction with it was clear and understandable $(76.7 \% ; \mathrm{M}=3.87)$, believing that they could easily become competent at using it (76.7\%; $\mathrm{M}=3.83$ ). Those perceiving that learning was made easy with ThingLink constituted almost $77 \%$ of the sample 
$(\mathrm{M}=3.83)$. A large majority also perceived that ThingLink required little or no effort to use as a learning aid $(70 \% ; \mathrm{M}=3.83)$. About $60 \%$ agreed the app would appeal to both occasional and regular users $(60 \% ; \mathrm{M}=3.63)$, while a lesser percentage reported seeing no inconsistencies in ThingLink as a learning aid (56.7\%; $\mathrm{M}=3.57)$. Overall, the patterns of responses suggest that the subjects found the OAVD/ThingLink relatively easy to use. The construct's mean is 3.903 , which closely approaches a solid agreement that the app is easy to use.

\section{Effect on Arabic Vocabulary Knowledge}

The pretest and posttest scores on Arabic vocabulary knowledge obtained through the VKS, which was administered twice in the study, were compared using a paired-samples t-test. The results, presented in Table 8, show the subjects' scoring higher in their Arabic vocabulary knowledge in the posttest $(\mathrm{M}=60.60, \mathrm{SD}=16.117)$ than in the pretest $(\mathrm{M}=54.07, \mathrm{SD}=$ 15.335).

Table 8

The Subjects' Pretest and Posttest Scores after the OAVD Intervention ( $\mathrm{N}=30)$

\begin{tabular}{lccc}
\hline & Mean & Std. Deviation & Std. Error Mean \\
\hline Posttest & 60.60 & 16.117 & 2.943 \\
Pretest & 54.07 & 15.335 & 2.800 \\
\hline
\end{tabular}

Based on Table 9, the subjects' Arabic vocabulary knowledge in the posttest demonstrated a mean increase of 6.533 points, 95\% CI [2.18, 10.88] after a week of using the OAVD intervention. The t-test results indicate that the 6.533-point increase from the pretest to the posttest is statistically significant, $t(29)=3.071, p=.005, d=0.42$. The effect size of $d=0.42$ indicates a medium effect or a moderate practical importance of the intervention.

Table 9

Paired Samples T-Test Results $(\mathrm{N}=30)$

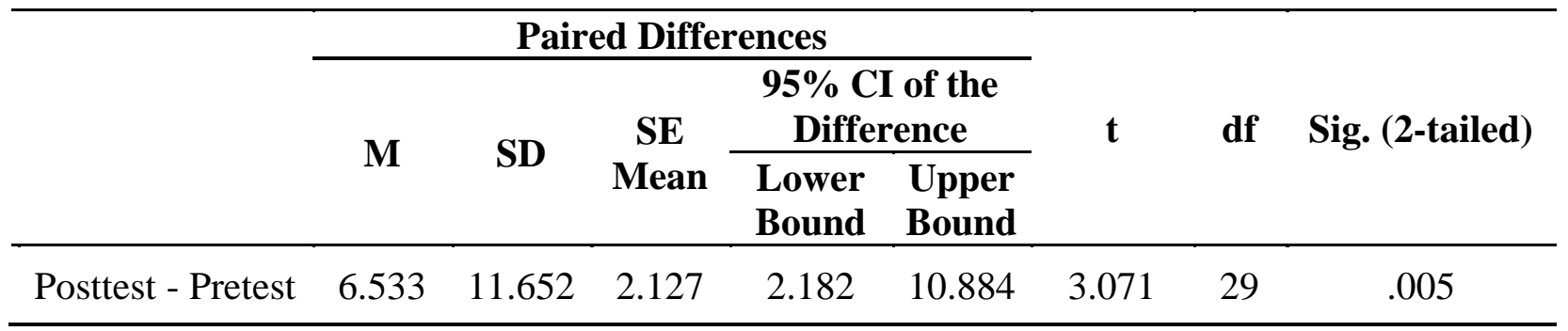




\section{DISCUSSION}

In general, this study was conducted to show the effectiveness of ThingLink as a $21^{\text {st }}$ century learning tool that can assist Arabic teachers in teaching the language to non-native learners. The study found that ThingLink was perceived to be beneficial in many ways by the subjects, particularly as a long-term study tool that enhances their acquisition of new Arabic vocabulary. The subjects also found ThingLink interesting and easy to use. Its interface was comprehensible enough to the subjects that they felt they could easily become competent in its use. Comparatively, ThingLink was rated higher in ease of use than usefulness, as the former's (perceived ease of use) mean percentage of agreement was $12.34 \%$ higher than the former (perceived usefulness). These findings are consistent with those of Davis (1989) and Andrias et al. (2013) which highlight the more influential role of perceived ease of use in impacting users' decision to adopt a new technology. The findings also suggest that ThingLink is an effective Arabic vocabulary learning application for non-native Arabic language students.

The effectiveness of ThingLink in facilitating non-native students' learning of Arabic vocabulary was demonstrated by the paired sample t-test results, which found a statistically significant increase in the subjects' posttest scores. After using the OAVD, the subjects rated themselves substantially higher (i.e., by an average of 6.53 points) on the VKS. What this means is when filling out the VKS, the subjects felt they understood the new vocabulary better after learning them using ThingLink compared to the traditional word study method. However, the effect size of the intervention was only moderate at Cohen's $d=0.42$. This could have been influenced by the subjects' already high prior knowledge before the OAVD intervention, which they had acquired through the researchers' teaching of the new vocabulary using direct instruction at the start of the study. Due to this flaw in the research design and to the lack of a control group, the actual impact of ThingLink (or the OAVD) on non-native students' acquisition of Arabic vocabulary could not be fully determined. Thus, future studies looking into ThingLink's effectiveness should address this design limitation by employing a more methodologically accurate pretest-posttest control group design.

The findings also point to the benefits of using technology in language teaching and learning, highlighting the fact that technology applications in learning Arabic vocabulary, specifically, are likely to result in better student learning outcomes than traditional language teaching approaches. However, learning institutions should be mindful of the readiness criteria that should characterize technology users prior to any decision to adopt a technology tool in the classroom. As illustrated in Chapnick's readiness model (2000), technology should only be adopted if all eight (8) criteria of preparedness are well in place. The criteria are technological, equipment, psychological, financial, human resource, environment, sociology and content readiness. Where the use of ThingLink is concerned, teachers should be prepared in the technological, equipment and content dimensions, while students should be ready to adopt ThingLink in terms of their mindset and attitude (i.e., psychological readiness) and ICT competencies (i.e., technological readiness) 


\section{CONCLUSION}

In light of the findings, it is implicit that the pedagogy for teaching Arabic vocabulary to the current generation of digital learners should be eclectic and varied, combining both traditional and modern approaches of teaching. Particularly, teachers should not use the same instructional methods and strategies from the beginning until the end of a semester. They should be diverse, knowledgeable and well-prepared in creating interactive and engaging teaching materials that draw students' interest in mastering Arabic vocabulary. Since students have different ability levels, learning styles, personalities, so on and so forth, they require different approaches that suit their learning styles. Some might be fast learners, while others might be slower or lesser in ability. A variety of instructional strategies will increase student motivation and improve their achievements. In future research, it may be useful to study the use of ThingLink in teaching Arabic vocabulary to different groups, namely special needs students, advanced students, or adult learners. This can be considered a significant step towards a wider adoption of ThingLink in Malaysian learning institutions. With the use of this app, an abundance of creative educators and students could be produced as ThingLink is a relevant tool that can meet the needs of $21 \mathrm{st}$ century education. 


\section{REFERENCES}

Adnan, A. H., Fahmi Zaidi, A. R., Azlina, A. B., \& Wan Salihin, W. A. (2016). The effects of perceived usefulness and perceived ease of use on continuance intention to use egovernment. Procedia Economics and Finance, 35, 644-649. Available at: https://doi.org/ 10.1016/S2212-5671(16)00079-4

Alasraj, A., \& Alharbi, H. (2014). The effectiveness of blended learning in teaching arabic as a second language. International Journal of Research in Humanities and Social Studies, $1(1), 13-17$.

Aliyu, A., Nurazan, M. R., Siti Salwa, M. N., \& Ibrahim, B. (2018). The application of web 2.0 tools to determine receptive skills among malay learners of arabic language at the universiti sultan zainal abidin (unisza). E-Academia Special Issue TeMIC, 1-7. Available at: https://doi.org/ 10.24191/e-aj.v7iSI-TeMIC18.5379

Andrias, R., Tanakinjal, G., Ag. Asri, A. I., \& Sondoh Jr., S. (2013). Perception and behavioral intention towards web 2.0 tools in education: A study among university students in malaysia. Proceedings of the 6Th International Conference of the Asian Academy of Applied Business $(A A A B)$. Bandung, Indonesia.

Appasamy, P. (2018). Fostering student engagement with digital microscopic images using thinglink, an image annotation program. Journal of College Science Teaching, 47(5), 1621.

Aromahu, R. M., \& Wirabhakti, A. (2019). Designing teaching instruction in teaching writing procedure text by using thing-link application at senior high school. English Learning and Teaching Research (ELTERA), 1(1).

Chandrasekera, T., \& Yoon, S. Y. (2018). Augmented reality, virtual reality and their effect on learning style in the creative design process. Design and Technology Education, 23(1), $55-75$.

Chapnick, S. (2000). Are you ready for e-learning? Available from: http://blog.uny.ac.id/nurhadi/files/2010/08/are_you_ready_for_elearning.pdf

Chin, M. (2014). The effectiveness of input and output in vocabulary acquisition among primary ESL learners (Unpublished Master's Thesis). University of Malaya.

Davis, F. D. (1989). Perceived usefulness, perceived ease of use, and user acceptance of information technology. MIS Quarterly, 319-340.

De Vaus, D. (2002). Surveys in social research (5th ed.). Australia: Allen \& Unwin.

Farmer, L. (2011). Teaching digital citizenship. In E-Learn: World Conference on E-Learning in Corporate, Government, Healthcare, and Higher Education, 99-104.

Ghasemi, A., \& Zahediasl, S. (2012). Normality tests for statistical analysis: a guide for nonstatisticians. International Journal of Endocrinology and Metabolism, 10(2), 486-489. https://doi.org/10.5812/ijem.3505

Hasan, M., \& Al-Hasani, S. M. A. (2019). Anxiety in learning arabic language for the students: a study of selected two language centers in Dhaka, Bangladesh. Journal of Literature, Languages and Linguistics, 55, 35-38. 
Inozemtseva, K., Kirsanova, G., Troufanova, N., Semenova Y. (2018). Using thinglink digital posters in teaching esp to business and economics students: A case study of bauman moscow state technical university, ICERI 2018 Proceedings, 3487-3492.

Boyle, J. (2015). Edutainment or Effective Technology Integration? How to make differentiation drive your technology-integrated instruction. Retrieved from http://www.literacy2point zero.com/download/IRA-EdTech-Article-Jennifer-Boyle.pdf

Konstantinidis, A., Theodostadou, D. \& Pappos, C. (2013). Web 2.0 tools for supporting teaching. Turkish Online Journal of Distance Education, 14(4), 287-295.

Leow, F. T., \& Neo, M. (2014). Interactive multimedia learning: innovating classroom education in a malaysian university. Turkish Online Journal of Educational Technology, 13(2), 99-110.

Lund, A. M. (2001). Measuring usability with the use questionnaire. Usability interface, $8(2)$, 3-6.

Makhoul, B., \& Sabah, K. (2019). Academic vocabulary knowledge and reading comprehension skills among seventh-graders in arabic as 11. Journal of Psycholinguistic Research, 1-16. https://doi.org/10.1007/s10936-019-09630-5

Martinez, S. G. (2010). Using web resources to support teachers and students with the teaching and practice of listening comprehension. Encuentro, 19, 20-31.

Mohamad Rofian, I., Awatif, A. R., Md Noor, H., Abdul Razif, Z., Hairun Najuwah, J., Ku Fatahiyah, K. A., \& Nor Syaidah, B. (2013). Persepsi pelajar terhadap kaedah pengajaran bahasa arab oleh pensyarah institusi pengajian tinggi di malaysia. Prosiding International Conference on Islamic Education 2013, ICIED, 911-916.

Mohamed Ali, H. M. (2013). Study on second language learners of arabic: an error analysis approach. By jassem ali jassem. Intellectual Discourse, 9(1). Available at: https://journals.iium.edu.my/intdiscourse/index.php/islam/article/view/475

Muhammad Sabri, S., \& Mohammad Taufiq, A. G. (2016). The design of computer courseware in teaching arabic language via website for students with the specialization of tourism at poly-tech college of mara at kelantan darul naim. Journal of Linguistic and Literary Studies, 7(1), 75-92.

Muhamad Khairul, A., Airil Haimi, M. A., Ahmad Ariffuddin, Y., Muhammad Anwar, M. K., \& Nurul Nadiah, M. K. (2019). Using new technologies to teach english in malaysia issues and challenges. Proceedings of International Invention, Innovative \& Creative (InIIC) Conference, Series 1/2019, (June), 203-207. Senawang, Negeri Sembilan: MNNF Network (ed.).

Norfaezah, M. H. (2014). Effective technique of teaching and learning arabic language in the classroom: A case study in selected national religious secondary schools (smka) in selangor. Paper presented at 2015 International Conference on Language, Literature, Culture \& Education (ICLLCE), 113-118.

Norfaezah, M. H. (2015). The teaching and learning strategies used in classroom: a case study in national religious secondary schools (smka) in selangor, malaysia. Proceedings of Phuket the International Conference on Language, Education \& Innovation, 75-83. 
Nur Farhanah, A.H., \& Arifin, M. (2017). The effects of storytelling on primary students' arabic vocabulary acquisition and interest. IIUM Journal of Educational Studies, 5(2), 20-38.

Nurkhamimi, Z., \& Muhammad Sabri, S. (2016). Multimedia courseware for teaching arabic vocabulary: Let's learn from the experts. Universal Journal of Educational Research, 4(5), 1167-1172. Available at: https://doi.org/10.13189/ujer.2016.040 529

Paivio, A. (1991). Dual coding theory: retrospect and current status. Canadian Journal of Psychology, 45(3), 255-287.

Perikos, I., Grivokostopoulou, F., Kovas, K., \& Hatzilygeroudis, I. (2015). Assisting tutors to utilize web 2.0 tools in education. International Association for Development of the Information Society, 121-128.

Raja Hazirah, R. S., Nik Murshidah, N. D., Rahimah, E., Nooranida, A., Zaiton, M., Normila, N., \& Mohd Taufiq, T. (2017). Role-playing technique in teaching arabic communication: a case study at universiti sultan zainal abidin in malaysia. International Journal of Academic Research in Business and Social Sciences, 7(10), 309-318. Available at: https://doi.org/ 10.6007/IJARBSS/v7-i10/3379

Shamshuritawati, S. (2019). Statistics for non-statisticians: Basic guide to spss (2nd ed.). Kedah: Khazanah Darul Aman.

Sueraya, C. H., Ahmed, I. H., Arifin, M., Wan Rusli, W. A. \& Rawash, F. M. M. (2016). Challenges in learning to speak arabic. Journal of Education and Practice, 7(24), 80-85.

Taha, A. (22 April, 2019). Personal interview.

Tautkevičienè, G., \& Dubosas, M. (2014). The purposes of students' use of web 2.0 tools for learning at the university. Journal of Emerging Trends in Computing and Information Sciences, 5(12), 962-967.

Wesche, M., \& Paribakht, T. S. (1996). Assessing second language vocabulary knowledge: Depth versus breadth. Canadian Modern Language Review, 53(1), 13-40.

Zunita, M. M, Harun, B., Lubis, M. A., \& Nurul Kamalia, Y. (2016). Teaching and learning arabic vocabulary: from a teacher's experiences. Creative Education, 7(03), 482-490. Available at: https://doi.org/10.4236/ce.2016.73049

Zunita, M. M., \& Harun, B. (2016). Receptive vocabulary knowledge or productive vocabulary knowledge in writing skill, which one important? International Journal of Academic Research in Business and Social Sciences, 6(11), 261-271. Available at: https://dx.doi.org/ 10.6007/ ijarbss/v6-i11/2395 